\title{
THE EXTENSION OF GEOGRAPHICAL INDICATION PROTECTION: NECESSARY FOR DEVELOPING COUNTRY
}

\author{
Mas Rahmah* \\ Department of Civil Law, Faculty of Law Universitas Airlangga, Surabaya \\ Jalan Darmawangsa Dalam Selatan, Surabaya, Jawa Timur 60286
}

\begin{abstract}
This paper analyses the need of extension of Geographical Indication (GI) protection since the current protection under Trade Related Aspect of Intellectual Property Rights (TRIPS) is insufficient to cover all products as a result of discriminatory provisions in TRIPS regulating a greater protection to wines and spirits only and different level of GI protection under Article 22 and Article 23 TRIPS. This paper then assumes that the extensive GI protection for all products should be supported because it would give greater benefits particularly to developing countries such as prevent the free riding, attract regional investment and obtain market power.
\end{abstract}

Keywords: geographical indication, TRIPS, developing countries.

\section{Intisari}

Perlindungan Indikasi Geografis (IG) perlu diperluas tidak hanya pada produk tertentu seperti wines dan spirits karena perlindungan IG diatur di dalam TRIPS tidak cukup memberikan perlindungan kepada semua produk sebagai akibat perbedaan pengaturan di TRIPS yang memberikan perlindungan lebih kepada wines dan spirits saja dan adanya perbedaan tingkat perlindungan pada Pasal 22 dan 23 TRIPS. Perluasan perlindungan IG harus didukung karena akan memberikan manfaat khususnya kepada negara berkembang. Perluasan perlindungan IG dapat melarang pemboncengan reputasi, menarik investasi dan meningkatkan kekuatan produk negara berkembang di pasaran.

Kata Kunci: indikasi geografis, TRIPS, negara berkembang.

\section{Pokok Muatan}

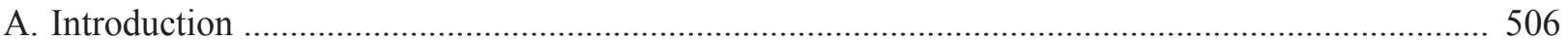

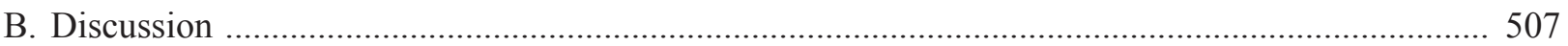

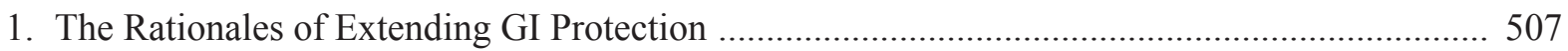

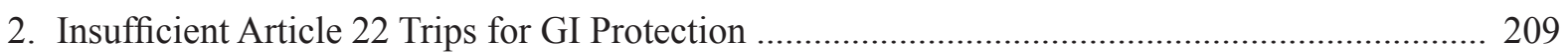

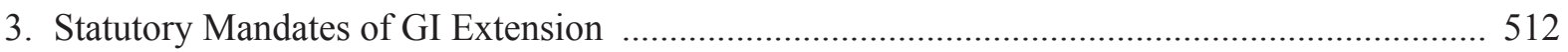

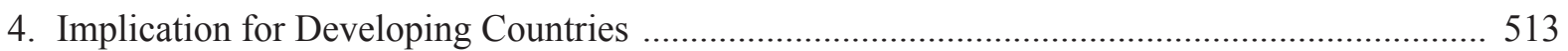

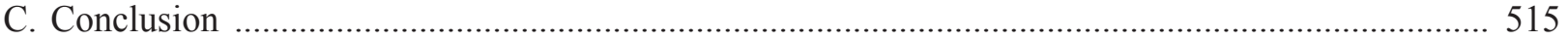




\section{A. Introduction}

GI has been protected under Paris Convention, Madrid and Lisbon Agreements administered by the World Intellectual Property Organization, however these agreements lack of a coordination, uniformity, and dispute settlement mechanisms influencing not significantly to the protection of GIs at international level. ${ }^{1}$ The internationalization of GI presents a significant advancement when protected under TRIPS Agreement in 1994.

According to Article 22 (1) of TRIPS agreement, GI is defined as indications, which identify a good as originating in the territory of a member, or a region or locality in that territory, where a given quality, reputation or other characteristic of the good is essentially attributable to its geographical origin. Another provisions of TRIPS regulating GI is Article 22.2 $2.3^{3}, 4^{4}$ and $23 . .^{5}$ Article 22 provides the general level of protection applicable to all GI products and prohibits the use of misleading indications or indications which constitute an act of unfair competition. Whereas, Article 23 of TRIPS provides a higher level of protection for wine and spirits prohibiting GI use in connection with products not originating from the designated geographical region, regardless of whether the true origin is indicated or it is used in conjunction with words such as "kind" or "type". 6 It means that Article of 22 of TRIPS provides the lower level protection than the Article 23 of TRIPS limited to the wine and spirit only. Therefore, the limited scope of GI protection under Article 22 TRIPS renders some WTO member states to ask extension of GI protection to all products.

The issue of extending Article 23 TRIPS for protection of GI to all products has been controversial debate in WTO forum. The opponents of extension such as the United States, Canada, Australia, New Zealand, South Africa, and Argentina, argue that current GI protection under Article 22 TRIPS is sufficient and it should be tried to is interpreted more extensively before extending the scope of Article 23. They assume that The GI extension would be expensive and hard to justify as such extension will be burdensome, costly and bring little benefit to GI users. ${ }^{7}$ However, the proponents ${ }^{8}$ argue that existing GI protection under TRIPS is not sufficient because TRIPS currently provides the greater protection only for wines and spirits and clearly discriminates other products. ${ }^{9}$ The extension of GI protection is important to confer the more effective level of protection of Article 23 TRIPS to all products.

Cerkia Bramley, et al., 2013, Developing Geographical Indications in the South, Springer, New York, pp. 2-3.

In respect of geographical indications, Members shall provide the legal means for interested parties to prevent: (a) the use of any means in the designation or presentation of a good that indicates or suggests that the good in question originates in a geographical area other than the true place of origin in a manner which misleads the public as to the geographical origin of the good; and (b) any use which constitutes an act of unfair competition within the meaning of Article 10bis of the Paris Convention (1967).

A Member shall, ex officio if its legislation so permits or at the request of an interested party, refuse or invalidate the registration of a trademark which contains or consists of a geographical indication with respect to goods not originating in the territory indicated, if use of the indication in the trademark for such goods in that Member is of such a nature as to mislead the public as to the true place of origin.

The protection under paragraphs 1,2 and 3 shall be applicable against a geographical indication which, although literally true as to the territory, region or locality in which the goods originate, falsely represents to the public that the goods originate in another territory.

(a) Each Member shall provide the legal means for interested parties to prevent use of a geographical indication identifying wines for wines not originating in the place indicated by the geographical indication in question or identifying spirits for spirits not originating in the place indicated by the geographical indication in question, even where the true origin of the goods is indicated or the geographical indication is used in translation or accompanied by expressions such as "kind", "type", "style", "imitation" or the like; (b) The registration of a trademark for wines which contains or consists of a geographical indication identifying wines or for spirits which contains or consists of a geographical indication identifying spirits shall be refused or invalidated, ex officio if a Member's legislation so permits or at the request of an interested party, with respect to such wines or spirits not having this origin; (c) In the case of homonymous geographical indications for wines, protection shall be accorded to each indication, subject to the provisions of paragraph 4 of Article 22. Each Member shall determine the practical conditions under which the homonymous indications in question will be differentiated from each other, taking into account the need to ensure equitable treatment of the producers concerned and that consumers are not misled; and (d) In order to facilitate the protection of geographical indications for wines, negotiations shall be undertaken in the Council for TRIPS concerning the establishment of a multilateral system of notification and registration of geographical indications for wines eligible for protection in those Members participating in the system. Ibid

Malcolm Spence, "Geographical Indications (Should We Extend Ourselves Further?)", http://www.crnm.org/documents/studies/staff\%20 papers/Trade_Hot_Topics_181_by_Malcolm_Spence.pdf, accessed on 12 March 2013.

The European Union, Switzerland, Hungary, Sri Lanka, Bulgaria, India, Kenya, Jamaica, Egypt, Cuba, Dominican Republic, Honduras, Indonesia, Nicaragua, Pakistan, Turkey, Venezuela, the Czech Republic, Iceland, Liechtenstein, Slovenia and the African Group are the main supporters of the GI extension.

Malcolm Spence, Loc.cit. 
This paper will discuss the need of the extension of GI protection for developing countries. To visualize the idea, the paper will analyses the rationales of extending GI protection, the statutory mandates for the extension of GI protection, and the implication the extension for developing countries. Therefore, the second part of the paper will describe the argument against and pro will first before concluding the rationales behind the extension of GI protection. Furthermore, the third part of the paper will expose the contention of insufficient protection under the Article 22 and 23 of TRIPS for all products by analysing the discriminatory provision in those articles which provides a greater protection to wines and spirits only. This part will describe the disparity level of protection between article 22 and 23 of TRIPS, and unnecessary test or requirement for protection in Article 22 such as misleading and unfair competition test, while Article 23 only prohibits any use of a GI on wines or spirits that do not originate in the designated geographical region. Consequently, standard of protection under Article 23 allows producers from other regions to use GI and free-ride on reputation without infringement as long as the product's true origin is indicated. At the fourth section, this paper will explore the statutory mandates for the extension of GI protection both based on Article 24 TRIPS and Doha Declaration. At the further section, the implication of the extension of GI protection will be exposed such as putting producers of developing countries on an equal footing to draw benefits from GI protection, preventing the free riding of local products, attracting investment in regional products and helping developing countries to obtain the greater market power.
B. Discussion

1. The Rationales of Extending GI Protection

\section{a. Argument Against and Pro} Extension

Argentina, Australia, Canada, Chile, Guatemala, New Zealand, Paraguay and the United States oppose the extension of additional protection to products other than wines and spirits. In their view, extension of the scope of Article 23 to products other than wines and spirits goes beyond the mandate in Article 24 (1). ${ }^{10}$ However, countries mainly from Asia, Europe and Africa supporting of extending the GI protection argue that additional protection should not be limited to wines and spirits. ${ }^{11}$ It is important to include other products under the higher protection in Article 23 because the additional protection for other products would rectify the imbalance caused by special protection of wines and spirits.

Opponents also say that there is no evidence that Article 22 does not manage to protect GI for products other than wines and spirits. Definition of GI in Article 22 (1) is much broader enough and also applies to other products such as industrial or artisan products that enjoy a particular reputation due to manufacturing know-how. ${ }^{12}$ They further argue that there is lack evidence whether extending GI protection would lead to a more effective protection than is already afforded to those products under Article 22. However, supporters argue that there is discrimination protection between Article 22 and Article 23 providing the greater protection for wines and spirits. ${ }^{13}$ They also argue that there is no logical or legal reasons

\footnotetext{
O’Connor, 2003, Geographical Indications in National and International Law, O’Connor and Company, Brussel, p. 158. Ibid.

2 Christopher Heath, Anselm Kamperman Sanders (Ed.), 2009, New Frontiers of Intellectual Property Law: IP and Cultural Heritage Geographical Indications - Enforcement - Overprotection, Hart Publishing, Oregon, p. 119.

13 C. Niranjan Rao, "Geographical Indication in Indian Context: a Case Study of Darjeeling Tea”, Economic and Political Weekly, Vol. 40 No. 42, October 2005 , p. 8 .
} 
justifying different level of protections of GI. ${ }^{14}$ Article 22 requiring consumer's misleading or producer's unfair competition, creates legal uncertainty, undue burden and trade distortions. These requirements place a significantly higher threshold and present problem of free-riding and risk of a GI being rendered generic.

Opponents assume that there is no legal basis for extension as the negotiating mandate in Article 24.1 concerns only "individual geographical indications for wines and spirits", ${ }^{15}$ not for whole product areas. However, indeed Article 24.1 mandates negotiations for GI-extension to products other than wines and spirits. It is explained that a 'narrow' reading of Article 24.1 only focussed on wines and spirits would further aggravate the hierarchy in the levels of GI protection.

Opponents suggest that GI-extension will involve additional costs for governments in legal, financial and administrative burden for implementing extension ${ }^{16}$. They argue that extension may need the introduction of new legal mechanisms, the financial and administrative costs of which would outweigh the benefits of extension ${ }^{17}$. However, worries about additional costs to governments are overstated ${ }^{18}$. Extension should not involve new additional legal or administrative burden as TRIPS members already have these mechanisms if they properly comply with Ar- ticle 23. Furthermore, members are still free to protect GIs through their existing legal regimes as they see fit under Article 1.1.TRIPS. Article 23 only requires legal means to prevent misuse, therefore as long as members provide some way to give effect to Article 23 GIs, they are free to minimize costs.

Opponents argue that extension would create additional costs for consumers resulting from consumer confusion caused by the need to re-name and re-label products, as well as by the disappearance of terms customarily used to identify products. ${ }^{19}$ However, rebelling only applies where some products illegitimate using a geographical indication is in same product category. ${ }^{20}$ Also, rename and re-label products seems not only logical but also justified taking into account the consumers protection and confusion, when the deceptive label is used. ${ }^{21}$ The consumers confusion on account of new labels will be a short-term disruption and effective marketing and promotion by 'right-full holders' of GIs could ease the adjustment process.

Opponents argue extension needs additional cost for producers for trade and production disruption. Arguably, extension may constitute a burden for producers who rely on this technique, but this is only a onetime cost. The economic long-term benefits of extending the more effective protection of GIs would clearly in any case outweigh the costs for the few cases of relabeling. ${ }^{22}$

14 World Trade Organization, "Work on Issue Relevant to the Protection of Geographical Indications: Extension of the Protection for Geographical for Wines and Spirits to Geographical Indications for Other Products", Communication from Bulgaria, Cuba, Mauritius, Nigeria, The Czech Republic, Egypt, Iceland, India, Jamaica, Kenya, Liechtenstein, Pakistan, Slovenia, Sri Lanka, Switzerland, Turkey and Venezuela", Paper IP/C/W/247/Rev.1, WTO Geneva, 2001, p. 5 (hereinafter WTO I).

15 Roland Knaak, "The Protection of Geographical Indications According to the TRIPS Agreement", in Friederich-Karl Beier \& Gerhard Schricker (Eds.), 1996, From GATT to TRIPS-The Agreement on Trade-Related Aspects of Intellectual Property Rights, Wiley-VCH, Munich, pp. 135-139.

16 Bernard O’Connor, 2004, The Law of Geographical Indications, Cameron May, London, p. 35.

17 Council for Trade-Related Aspects of Intellectual Property Rights, "Communication from Argentina et al", Paper IP/C/W/289, June 29, 2001, pp. 14-18 (hereinafter Council for Trade-Related Aspects of Intellectual Property Rights I).

Aaron C. Lang, "On the Need to Expand Article 23 of the TRIPs Agreement”, Duke J. Comp. \& Int'l L., Vol. 6, 2006, p. 506.

Council for Trade-Related Aspects of Intellectual Property Rights I, Op.cit., p. 21.

Bernard O’Connor, Op.cit., p. 354.

Ibid.

Felix Addor and Alexandra Grazioli, "Geographical Indications Beyond Wines and Spirits: A Roadmap for a Better Protection for Geographical Indications in the WTO/TRIPS Agreement”, J. World Intell. Prop., Vol. 5, 2002, p. 882 (hereinafter Felix Addor, Alexandra Grazioli I). 
Opponent argue that extension would close market, block import and affect the producer's activities. ${ }^{23}$ Demanders do not dismiss these possibilities that no doubt changes in Article 23 will lead to trade disruption and narrowing market access for those producers who have been free-riding on reputable indications. However, producers in locations outside the designated geographical area can still produce and sell the goodnaturally without the use of the protected indication. The extension would not create a barrier to trade, but would instead promote trade and investment, in particular for all the developing and developed countries which depend on exports of GI commodities. ${ }^{24}$

\section{b. The Reasons for the Extension of GI Protection}

The applicable protection regime to GI for non wines and non spirits products is based on unclear and ambiguous rules. ${ }^{25}$ Uncertainty about the conditions in which producers operate will affect negatively for trade, investment and therefore for development. Thus, the legal certainty in the regulatory framework for the GI protection is clearly needed to put producers and their products on an equal position to draw benefits from GI. ${ }^{26}$ The more effective protection and facilitated enforcement under the additional protection of Article 23 to all products, will enhance international trade flows and prevent GI from becoming generic in the future and therewith from losing all their economic value.
Developing countries has interest in GI-extension because of the importance of the remunerative marketing of their agricultural, handicraft and artisan products. ${ }^{27}$ Only by extending the level of protection will help producers to adequately protect their investment and assist them in competing on the global market. ${ }^{28}$ The benefits of GIextension will foster sustainable development of local rural communities by encouraging a quality local products. It will also foster employment in decentralized regions, support the establishment of other economic activities such as tourism and contribute to preserving traditional knowledge and biodiversity. ${ }^{29}$ It is therefore crucial to enhance GI protection.

\section{Insufficient Article 22 TRIPS for GI Protection \\ Opponents argue that existing Article 22 is} sufficient enough for protection against misleading uses of $\mathrm{GI}^{30}$ and there is a lack of evidence of the ineffectiveness of Article 22 or of concomitant economic loss. However, Article 22 is not adequate enough as it creates three broad problems of: 'freeriding', the risk of rendering GIs as generic terms, and the uncertainty of and undue burden in enforcing GI-protection. Also, different requirements in Article 22 compared to Article 23 creates disparity level of protection and a significantly higher threshold.

\section{a. Unnecessary Misleading Test and Unfair Competition Requirement In enforcing GI protection, Article}

Bernard O’Connor, Op.cit., p. 352.

Ibid, at 324.

UNCTAD - ICTSD, 2005, The Resource Book on TRIPS and Development, Cambridge University Press, New York, p. 296.

Mathias Schaeli, "Perspectives for Geographical Indications: Extension of the Protection of Article 23 of the TRIPS Agreement to All Products: A Promising Solution for Developing An Appropriate International Legal Framework for the Protection of Geographical Indications", Paper WIPO/GEO/BEI/07/11, WIPO International Symposium on Geographical Indications, Beijing, 26-28 June 2007 , p. 2.

Ibid.

Ibid.

29 UNDP, “Geographical Indications as Trade-Related Intellectual Property”, Discussion Paper, Asia-Pacific Trade and Investment Initiative, UNDP Regional Centre, Colombo, January 2007, p. 11.

30 WTO Council for TRIPS, "Implications of Article 23 Extension, Communication from Argentina, Australia, Canada, Chile, the Dominican Republic, El Salvador, Guatemala, New Zealand, Paraguay, the Philippines, Chinese Taipei and the United States", Paper IP/C/W/386, November 2002, p. 2. 
$22.2^{31}$ TRIPS requires not only consumers misleading test, but also unfair competition test. $^{32}$ These requirements represent an imbalance that will unfairly distort trade between wine-producing countries and others. It is unfair burdens for producers of other goods to prove consumer confusion or unfair competition. The low standard in Article 22 will allow free-riding by the company from developed countries to rely on the investments and labour of other producers who have infused the GI with an outstanding reputation. ${ }^{33}$ As an infringement action under Article 22 requires the plaintiff to demonstrate that the public is misled by the use of the GI, as a result someone producing goods outside the region identified by the GI can exploit its reputation easily if the public is not confused by such use. ${ }^{34}$ Therefore, it is legal the unauthorized use of protected GIs under Article 22 if de-localizing qualifiers are used. $^{35}$

The free-riding enabled by Article 22 poses risks to the GI itself becoming generic. ${ }^{36}$ The distribution of the follow-on goods can have the effect of diluting or tarnishing the original GI. ${ }^{37}$ Worse yet, legally permissible free riding can render GIs generic. ${ }^{38}$ It cannot be denied that GIs are emptied of their legal effect by repeated free-riding. ${ }^{39}$ Therefore, the risk of GIs becoming generic is a "key reason" for demanding extension. ${ }^{40}$
Opponents argue that there is no need to worry about GIs being destroyed by free riding because the authentic goods originating in the designated geographical region will be recognized internationally. However, the development of the GI's reputation may be stifled by any free-riding that occurs before the original GI becomes internationally recognized as signifying distinctive quality. An additional result of the free-riding is the discouraging producers from making investments in GIs. Free riding reduces the returns on such investment, and many producers would rather take free rides than invest in unique indications. Therefore, it is critical to protect all GIs as vigorously as those in Article 23, in order to reward and stimulate investments in the world's markets.

Requirement of consumer confusion in Article 22 also creates legal uncertainty. Main goal of the WTO Agreement and a common interest of WTO Members is to establish and ensure a fair and predictable legal framework. ${ }^{41}$ However, this goal is undermined by the unsatisfactory provisions of Article 22. The public confusion as a prerequisite to an infringement may obfuscate the legal proceedings. ${ }^{42}$ The proof required under Article 22 allows wide judicial discretion, particularly to test public misleading. It is impossible to predict the court decision and judges may reach different

31 See Article 22 (2) TRIPS states that:

In respect of geographical indications, members shall provide the legal means for interested parties to prevent: (a) the use of any means in the designation or presentation of a good that indicates or suggests that the good in question originates in a geographical area other than the true place of origin in a manner which misleads the public as to the geographical origin of the good; (b) any use which constitutes an act of unfair competition within the meaning of Article 10bis of the Paris Convention 1967.

32 Malcolm Spence, Loc.cit.

33 Council for Trade-Related Aspects of Intellectual Property Rights, "Proposal from Bulgaria", Paper IP/C/W/247, March 29, 2001, pp. 10-11 (hereinafter Council for Trade-Related Aspects of Intellectual Property Rights II).

Ibid.

35 Felix Addor, Alexandra Grazioli I, Op.cit., p. 879

Council for Trade-Related Aspects of Intellectual Property Rights II, Op.cit., p. 12

Dwijen Rangnekar, "Geographical Indications: A Review of Proposals at the TRIPs Council: Extending Article 23 to Products Other than Wines And Spirits”, Issue Paper UNTAD-ICTSD, No. 4, June 2003, p. 8 (hereinafter Dwijen Ragnekar I).

Ibid.

Ibid, p. 33 .

WTO Council for TRIPS, Op.cit., p. 8.

Council for Trade-Related Aspects of Intellectual Property Rights II, Op.cit., p. 18.

Ibid, p. 10. 
decisions on whether the public is misled or not.

Opponents argued that Article 22 is sufficient to protect GIs, but that it is rarely used. ${ }^{43}$ However, the infrequency uses of Article 22 may imply that it is simply prohibitive to use in many cases. ${ }^{44}$ The burden of proof requirement in Article 22 creates excessive costs for plaintiffs. This cost may be prohibitive, especially for producers in developing countries. Plaintiffs may not proceed if the infringement is less than or if the infringement is on a small enough scale that the cost of and time-consuming litigation would outweigh the market damage.

\section{b. Disparity Level of Protection between Article 22 and Article 23}

Article 22 requires the higher threshold that the GI holders only have access to legal recourse if consumers have been misled by the infringing label or if its sale constituted an act of unfair competition, whereas Article 23 nullifies these requirements. To prevent the illegitimate use of GI under Article 23, producers of wines and spirits only prove that the products on which GI is used does not originate in the geographic area identified by its indication ${ }^{45}$, whereas producers of other goods needs not only prove that there is illegitimate use of the GI, but also such a use misleads the public or constitutes an act of unfair competition. ${ }^{46}$ Therefore, for wines and spirits, the level of protection is higher and is not conditional on whether there is unfair competition or the public is mislead.
The misleading test in Article 22 is "complicated and expensive. ${ }^{47}$ In contrast, there is no this test on the producers for wines and spirits. While holders of Article 23 GI are protected by a per se rule against unauthorized use, ${ }^{48}$ therefore, incur relatively few costs in litigating their GI claims ${ }^{49}$, GI holders of Article 22 face appreciable enforcement costs as a result of their burden of proof. The disparity level of protection in Article 22 and 23 has been debated in the WTO. ${ }^{50}$ The limited protection granted by Article 22 as compared to Article 23 of the TRIPS Agreement entails several deficiencies. Supporters GI-extension find no justification or rational basis for the continued existence of the two levels of protection in Article 22 and 23 TRIPS. ${ }^{51}$ Therefore, extending Article 22, which does not require the "misleading test" or evidence of unfair competition, will provide an adequate level of protection to GI for all products.

\section{c. No Mandate for Multilateral Re- gister}

TRIPS calls for negotiations to create a multilateral register for GIs on Article 23 goods,${ }^{52}$ but not for any other types of GI. It means that no mandate for multilateral register in Article 22. However, the multilateral registered applied in Article 23 should also be implemented to all products. If a multilateral register applied to all products, it would prevent free-riding and unintentional appropriation of GI. It would also enable GI holders to be on timely notice

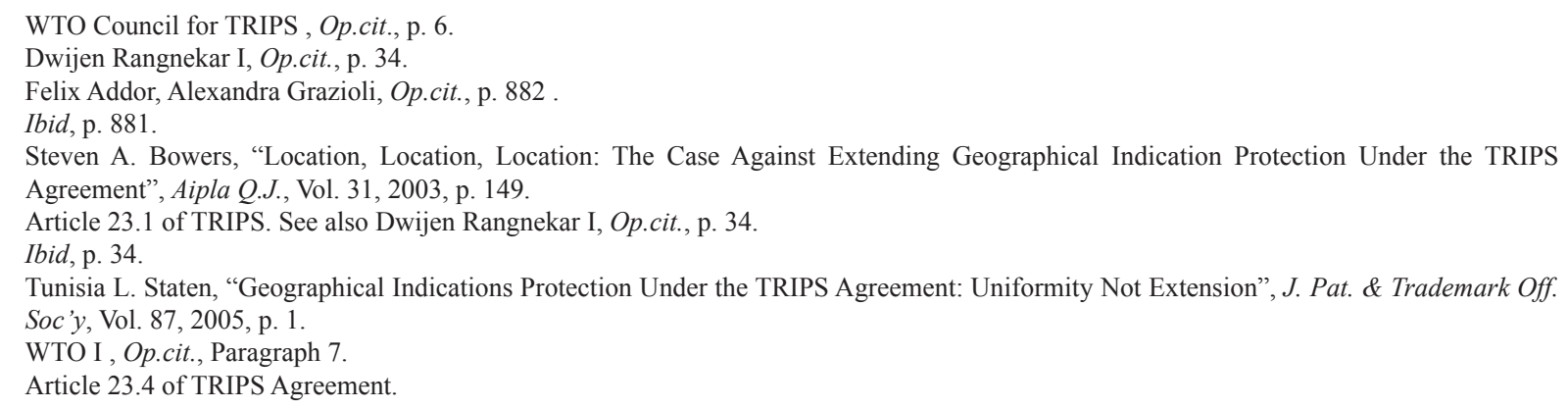


of these GIs and take appropriate measures such as denying trademark registration requests for trademarks containing registered GIs pursuant to Article 23.253. As GI's reputation requires significant investment and labour, timeliness in GI disputes is critical, and the timely notice offered by the multilateral register would benefit. The timely notice would also minimize costs to the producers of the infringing goods because they would be able to avoid the mistake of investing in marks that would eventually be discontinued. Without the register, a member might unwittingly register a conflicting trademark and forcing the legitimate holder of the GI to undo the damage in court. The register provides better protection to foreign GIs which the holders of these GIs would not have to go out of their way to prevent others from issuing infringing marks or to litigate such infringement.

In addition, a multilateral register would make it easier for GIs holders to defend their right in court and reduce the cost of this defence. If the registered GIs were given the presumption of eligibility for protection, the cost savings associated with the defence of a registered mark would be profound, as the plaintiff would bear no burden of proof. However, even if registered GIs were not given the presumption of eligibility for protection, ${ }^{54}$ the register would stand as strong evidence supporting the GI's legitimacy., In addition, registration is a useful tool to ensure equality of treatment between national and foreign geographical indications, and to being a practical instrument for importers, exporters, administrative and judicial authorities, producers and consumers. ${ }^{55}$

\section{Statutory Mandates of GI Extension}

\section{a. The Mandates of Article 24}

The debate in the TRIPS Council regarding the extension is the interpretation of Article 24, which ambiguously obliges Members to enter into negotiations 'aimed at increasing the protection of individual geographical indications under Article 23', while simultaneously ensuring that there is no reduction in 'the protection of geographical indications that existed in that Member immediately prior to the date of entry into force of the WTO Agreement' ${ }^{56}$ As Article 24 is ambiguous, there is disagreement between Member to negotiate the extension of Article 23 to all products.

Opponents argue that there is no direct reference to an extension in TRIPS although some reliance has been placed on Article 24(1) and (2). They emphasize that there is no mandate for negotiations the extension to all products since Article $24.1^{57}$ is explicitly focussed on "individual indications for wines and spirits". ${ }^{58}$ However, if Article 24.1 were taken to mean that there should only be forthcoming increases in protection for Article 23 goods (only wines and spirits),

53 European Communities, "Negotiations Relating to the Establishment of a Multilateral System of Notification and Registration of Geographical Indications-Issues for Discussion at the Special Session of the TRIPS Council of 28 June 2002-Informal Note", Paper JOB(02)/70, June 24, 2002, Paragraph 22.

54 Council for Trade Related Aspects of Intellectual Property Rights Special Session, "Proposal for a Multilateral System for Notification and Registration of Geographical Indications for Wines and Spirits Based on Article 23.4 of the TRIPS Agreement", Paper TN/IP/W/5, October 23, 2002. See also Council for Trade Related Aspects of Intellectual Property Rights Special Session, "Multilateral System of Notification and Registration of Geographical Indications for Wines (and Spirits)", Paper TN/IP/W/6, October 29, 2002, p. 2.

55 EU Proposal, Council for Trade Related Aspects of Intellectual Property Rights, "Implementation of Article 23.4 of the TRIPS Agreement Relating to the Establishment of a Multilateral System of Notification and Registration of Geographical Indications", Paper IP/C/W/107/ Rev.1, June 22, 2000, p. 2.

56 Ibid.

57 See Article 24(1) of TRIPS: Members agree to enter into negotiations aimed at increasing the protection of individual geographical indications under Article 23. The provisions of paragraphs 4 through 8 below shall not be used by a Member to refuse to conduct negotiations or to conclude bilateral or multilateral agreements. In the context of such negotiations, Members shall be willing to consider the continued applicability of these provisions to individual geographical indications whose use was the subject of such negotiations.

58 Roland Knaak, Loc.cit. 
then the groundless hierarchy between product categories would be exacerbated and it would add to the imbalances already existing in Article 22 and 23 which is not consistent with the spirit and basic objectives of the TRIPS Agreement. ${ }^{59}$

Proponents reason that Article 24.1 is general application to all products and the reference to extension. ${ }^{60}$ Article 24 requires Members to negotiate an extension of Article 23 to cover other types of GIs. In Article 24.1, "Members agree to enter into negotiations aimed at increasing the protection of individual geographical indications under Article $23^{, 61}$. It means that the universe of GIs should be expanded ${ }^{62}$.

Even if Article 24.1 were not construed to require negotiations regarding extension, Article $24.2^{63}$ still requires the Council to "take such actions as may be agreed to facilitate the operation and further the objectives of this Section". ${ }^{64}$ This provision can be read to instruct expanding the scope of Article 23. Furthermore, the TRIPS Council reported to the 1996 Ministerial Conference in Singapore explicitly 'that a review of the application of the provisions of the Section on Geographical Indications as provided for in Article 24.2 [...]". ${ }^{65}$

\section{b. Mandate of Doha Declaration}

Paragraph 18 of Doha Declaration ${ }^{66}$ simply mandates that issues related to the extension of GI protection would merely be negotiated in the Council for TRIPS, whereas there was specific agreement to negotiate the establishment of a register of geographical indications. ${ }^{67}$ Since then, more specific reference to the particular issue of extending protection was made in the Ministerial Statement coming out of the $6^{\text {th }}$ Meeting in Hong Kong in December, 2005. ${ }^{68}$ WTO members expressed different interpretations of Doha mandate. For instance, Argentina states that there is no agreement to negotiate the GI extension and consensus will be required in order to launch any negotiations on the issue of GI extension. However, supporters states that there is a clear mandate for extension under Doha Declaration and it requires immediate negotiations. ${ }^{69}$

\section{Implication for Developing Countries}

The first who suffer from the lack of "GI extension" are the producers particularly in developing countries who have little or no resources to allocate to costly and legally uncertain enforcement of their GI by complicated litigation requirements. Therefore, extending GI protection which does not require complicated requirement

\footnotetext{
WTO I, Op.cit., p. 6. See also Jim Keon, "Intellectual Property Rules for Trademarks and Geographical Indications: Important Parts of the New World Trade Order", in Carlos Correa \& Abdulqawi Yusuf (Eds.), 1998, Intellectual Property and International Trade: The TRIPS Agreement, Kluwer Law International, London, p. 174.

60 WTO I, Op.cit., Paragraph 12.

Article 24.1 of TRIPS

Aaron C. Lang, Op.cit, , p. 505.

63 See Article 24.2 of TRIPS: The Council for TRIPS shall keep under review the application of the provisions of this Section; the first such review shall take place within two years of the entry into force of the WTO Agreement. Any matter affecting the compliance with the obligations under these provisions may be drawn to the attention of the Council, which, at the request of a Member, shall consult with any Member or Members in respect of such matter in respect of which it has not been possible to find a satisfactory solution through bilateral or plural lateral consultations between the Members concerned. The Council shall take such action as may be agreed to facilitate the operation and further the objectives of this section.

64 Article 24.2 of TRIPS.

65 Council for Trade-Related Aspects of Intellectual Property Rights II, Op.cit., p. 14.

66 Doha Ministerial Declaration of 20 November 2001, WTO Doc WT/MIN/(01)/DEC/1

67 Mark Davidson, Loc.cit.

68 Ibid.

69 World Trade Organization, "Communication from Bulgaria, Czech Republic, EU, Hungary, Liechtenstein, Kenya, Mauritius, Nigeria, Pakistan, The Slovak Republic, Slovenia, Sri Lanka, Switzerland, Thailand and Turkey regarding Paragraphs 18 and 12 of the Draft Ministerial Declaration", Paper WT/MIN(01)/W/11, November 14, 2001 (available at http://www.wto.org/ (hereinafter WTO II). See also, World Trade Organization, "Communication from India, Bulgaria, Kenya and Sri Lanka regarding Paragraphs 18 and 12 of the Draft Ministerial Declaration”, Paper WT/MIN(01)/W/9, November 13, 2001 (hereinafter WTO III).
} 
such as the "misleading test" or unfair competition, will provide an adequate level of protection to GI for all products. The stronger GI protection would reduce the problem in Article 22 such as 'free-riding', the risk of rendering GIs as generic terms, and the uncertainty of and undue burden in enforcing GI-protection.

\section{a. Increasing Investment and Market Power}

The extensive GI protection would attract investment in regional products as strengthening or expanding any intellectual property right makes investments more secure and consequently raises levels of investment. Expanding the scope of Article 23 would increase the value of GI and encourage more quality and niche products to be put on the world's markets. Because there are unique products in developing countries, increased GI protection will attract investors to these regions.

Increased investment due to heightened GI protection would allow producers in developing countries to develop economies of scale. ${ }^{70}$ Development through foreign investment would help close the gap between developing and developed countries. To promote economic equality between the North and South, developing countries must be allowed to partake in the undeniable economic advantage of GIs. Therefore, there is the need to capitalize on the opportunity to increase investment in regional products by expanding the coverage of Article 23.

Additionally, extension would help developing countries gain market power because GI frequently protects the types of products common to developing countries.
GI have been identified as being especially promising protection because they tend to protect the types of goods that are most common to developing societies. If a good is to bear a GI, it must have special qualities attributable to the good's geographical source. ${ }^{71}$ GI goods tend to be from the rural, agricultural and handicraft sectors of the economy, further implicating the interests of developing countries. ${ }^{72}$

\section{b. Benefits Outweighs the Cost}

Althoughthe GIextensionwouldbenefit the developing world, it has been argued that extension would actually be disadvantageous to developing countries because their legal and administrative capacities are currently limited and would require costly expansion. ${ }^{73}$ However, developing countries need not be held to the same implementation obligations as developed counterparts. Extension of Article 23 could be accompanied by special exceptions for developing countries that soften the new obligations. The TRIPS itself states that "Members shall be free to determine the appropriate method of implementing the provisions of this Agreement within their own legal system and practice". ${ }^{74}$ Therefore, developing countries have discretion to comply TRIPS obligations and could find ways to minimize the cost of compliance following substantive changes in the TRIPS. Presumably, developing countries already have legal regime as they are already required to protect GI in Article 23. Thus, any new legal mechanisms should not be needed, although the scope of goods covered by Article 23 would be different if extension occurred..$^{75}$ Indeed, "unlike any other IP,

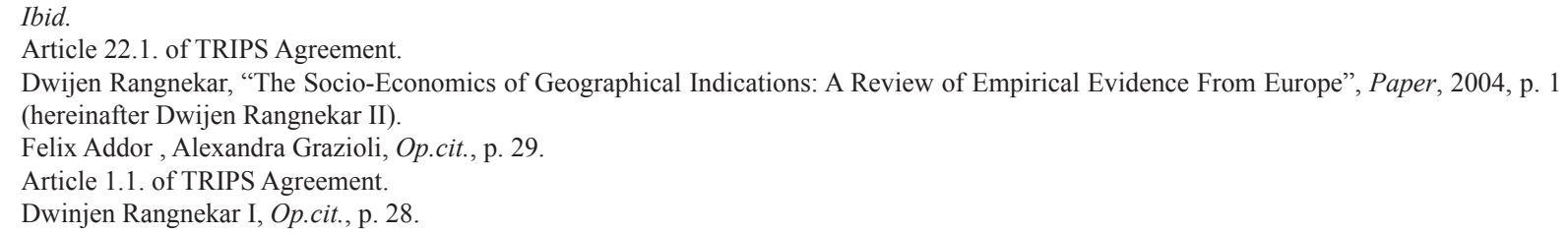


demanders for stronger protection include many developing countries". ${ }^{76}$ Developing counties will be much better off as a result of the additional GI protections. ${ }^{77}$ Developing countries stand to gain significantly and could benefit most from an effective and stronger GI protection. ${ }^{78}$ Therefore, limited short-term costs should not be treated as reasons to avoid opportunities for long-term development.

\section{Conclusion}

The issue of extending Article 23 protection to all geographical indications has have been the subject of on going negotiations in WTO forum and it has also been linked with the controversial issue of international trade. ${ }^{79}$ The extensive GI protection must be supported as current GI provision under TRIPS is insufficient and discriminative. Low standard of Article 22 and disparity hierarchy between Article 22 and 23 are also the reasons for extension which is mandated by Article 24 . Preventing free-riding including preventing GI being generic, as well as the positive effects of extension should be considered to support the GI extension.

\section{REFERENCES}

\section{A. Books}

Bramley, Cerkia, et al., 2013, Developing Geographical Indications in the South, Springer, New York.

Heath, Christopher and Anselm Kamperman Sanders (Ed.), 2009, New Frontiers of Intellectual Property Law: IP and Cultural Heritage Geographical Indications - Enforcement Overprotection, Hart Publishing, Oregon.

O'Connor, 2003, Geographical Indications in National and International Law, O'Connor and Company, Brussel. , 2004, The Law of Geographical Indications, Cameron May, London.

UNCTAD - ICTSD, 2005, The Resource Book on TRIPS and Development, Cambridge University Press, New York.

\section{B. Anthology}

Keon, Jim, "Intellectual Property Rules for Trademarks and Geographical Indications: Important Parts of the New World Trade Order", in Carlos Correa \& Abdulqawi
Yusuf(Eds.), 1998, Intellectual Property and International Trade: The TRIPS Agreement, Kluwer Law International, London.

Knaak, Roland, "The Protection of Geographical Indications According to the TRIPS Agreement", in Friederich-Karl Beier \& Gerhard Schricker (Eds.), 1996, From GATT to TRIPS-The Agreement on Trade-Related Aspects of Intellectual Property Rights, Wiley-VCH, Munich.

\section{Journal Articles}

Addor, Felix and Alexandra Grazioli, "Geographical Indications Beyond Wines and Spirits: A Roadmap for a Better Protection for Geographical Indications in the WTO/TRIPS Agreement", J. World Intell. Prop., Vol. 5, 2002.

, "Geographical Indications: Important Issues for Industrialized and Developing Countries", The IPTS Report, May 2003.

Bowers, Steven A., "Location, Location, Location: The Case Against Extending Geographical

Dwijen Rangnekar II, Op.cit., p. 1.

Felix Addor, Alexandra Grazioli I, Op.cit.., p. 29.

Felix Addor and Alexandra Grazioli, "Geographical Indications: Important Issues for Industrialized and Developing Countries", The IPTS Report, May 2003, p. 29 (hereinafter Felix Addor, Alexandra Grazioli II).

79 Burkhart Goebel, "Geographical Indications and Trademarks - The Road from DOHA”, Trademark Reporter, Vol. 93, 2003 , p. 987. 
Indication Protection Under the TRIPs Agreement”, Aipla Q. J. , Vol. 31, 2003.

Goebel, Burkhart, "Geographical Indications and Trademarks - the Road from DOHA", Trademark Reporter, Vol. 93, 2003.

Lang, Aaron C., "On the Need to Expand Article 23 of the TRIPs Agreement", Duke J. Comp. \& Int'l L., Vol. 6, 2006.

Staten, Tunisia L., "Geographical Indications Protection Under the TRIPS Agreement: Uniformity Not Extension", J. Pat. \& Trademark Off. Soc'y, Vol. 87, 2005.

\section{Paper}

Council for Trade Related Aspects of Intellectual Property Rights Special Session, "Proposal for a Multilateral System for Notification and Registration of Geographical Indications for Wines and Spirits Based on Article 23.4 of the TRIPS Agreement", Paper TN/IP/W/5, October 23, 2002 [Proposal for a Multilateral System].

"Multilateral System of Notification and Registration of Geographical Indications for Wines (and Spirits)", Paper TN/IP/W/6, October 29, 2002 [Multilateral System of Notification and Registration].

Council for Trade-Related Aspects of Intellectual Property Rights, "Communication from Argentina et al”, Paper IP/C/W/289, June 29, 2001.

, "Proposal from Bulgaria", Paper IP/ C/W/247, March 29, 2001.

EU Proposal, Council for Trade Related Aspects of Intellectual Property Rights, "Implementation of Article 23.4 of the TRIPS Agreement Relating to the Establishment of a Multilateral System of Notification and Registration of Geographical Indications", Paper IP/C/W/107/Rev.1, June 22, 2000.

European Communities, "Negotiations Relating to the Establishment of a Multilateral System of Notification and Registration of Geographical Indications"- Paper JOB(02)/70, Issues for Discussion at the Special Session of the TRIPS Council of 28 June 2002-Informal Note, June 24, 2002.

UNDP, "Geographical Indications as Trade-Related Intellectual Property", Discussion Paper, Asia-Pacific Trade and Investment Initiative, UNDP Regional Centre, Colombo, January 2007.

World Trade Organization, "Communication from Bulgaria, Czech Republic, EU, Hungary, Liechtenstein, Kenya, Mauritius, Nigeria, Pakistan, The Slovak Republic, Slovenia, Sri Lanka, Switzerland, Thailand and Turkey regarding paragraphs 18 and 12 of the Draft Ministerial Declaration", Paper WT/ $\operatorname{MIN}(01) / W / 11$, November 14, 2001.

, "Communication from India, Bulgaria, Kenya and Sri Lanka regarding paragraphs 18 and 12 of the Draft Ministerial Declaration", Paper WT/MIN $(01) / W / 9$, November 13, 2001.

"Work on Issue Relevant to the Protection of Geographical Indications: Extension of the Protection for Geographical for Wines and Spirits to Geographical Indications for Other Products", communication from Bulgaria, Cuba, Mauritius, Nigeria, The Czech Republic, Egypt, Iceland, India, Jamaica, Kenya, Liechtenstein, Pakistan, Slovenia, Sri Lanka, Switzerland, Turkey and Venezuela", Paper IP/C/W/247/Rev.1, WTO Geneva, 2001.

WTO Council for TRIPS, "Implications of Article 23 Extension, Communication From Argentina, Australia, Canada, Chile, the Dominican Republic, El Salvador, Guatemala, New Zealand, Paraguay, the Philippines, Chinese Taipei and the United States", Paper IP/ $C / W / 386$, November 8, 2002.

Rangnekar, Dwijen, "Geographical Indications: A Review of Proposals at The TRIPs Council: Extending Article 23 to Products Other Than Wines And Spirits", Issue Paper UNTADICTSD, No. 4, June 2003. 
Rangnekar, Dwijen, "The Socio-Economics of Geographical Indications: A Review of Empirical Evidence from Europe", Paper, 2004.

Rao, C. Niranjan, "Geographical Indication in Indian Context: A Case Study of Darjeeling Tea", Working Paper of Indian Council For Research on International Economics Relation, September 2003.

Schaeli, Mathias, "Perspectives for Geographical Indications: Extension of the Protection of Article 23 of the TRIPS Agreement to All Products: A Promising Solution for Developing an Appropriate International Legal Framework for the Protection of Geographical Indications", Paper WIPO/ GEO/BEI/07/11, WIPO International
Symposium on Geographical Indications, Beijing, China, 26-28 June 2007.

\section{E. Internet Articles}

Spence, Malcolm, "Geographical Indications (Should We Extend Ourselves Further?)", http://www.crnm.org/documents/studies/ staff\%20papers/Trade_Hot_Topics_181_by_ Malcolm_Spence.pdf, accessed on 12 March 2013.

\section{F. Regulation}

Trade Related Aspect of Intellectual Property Rights (TRIPS) Agreement.

\section{G. Miscellaneous}

Doha Ministerial Declaration of 20 November 2001, WTO Doc WT/MIN/(01)/DEC/1. 